\title{
KONFLIK SOSIAL DALAM ANTOLOGI PUISI ESAI: SERAT KEMBANG RAYA KARYA FATIN HAMAMA, DKK (TINJAUAN SOSIOLOGI SASTRA)
}

\author{
Aji Septiaji ${ }^{1}$ \\ Universitas Majalengka \\ ajiseptiaji@gmail.com
}

\begin{abstract}
Abstrak
Sastra bersumber dari dalam masyarakat dan akan berdampak pengaruhnya pada masyarakat. Bahkan, adanya hubungan timbal balik antara sastrawan, sastra, dan masyarakat. Hubungan tersebut berupa konteks sosial pengarang, sastra sebagai cerminan masyarakat, dan fungsi sosial sastra. Puisi esai hadir sebagai genre sastra baru dalam khazanah kesusastraan Indonesia. Tahun 2012 menjadi kontroversi bagi puisi esai, yaitu kemunculan Denny JA sebagai konsultan politik yang menggagas antologi puisi esai Atas Nama Cinta yang sarat diskriminasi sosial. Puisi esai dianggap sebagai jelmaan pemikiran dan pengalaman terhadap kondisi sosial di masyarakat saat ini. Namun, tetap mampu dicerna oleh masyarakat. Adapun puisi esai harus memenuhi tiga syarat, yaitu (1) puisi esai mengeksplor sisi batin individu yang berada dalam sebuah konflik sosial; (2) puisi esai menggunakan bahasa yang mudah dipahami; dan (3) puisi esai adalah fiksi, boleh saja memotret tokoh ril yang hidup dalam sejarah. Namun, realitas tersebut diperkaya dengan aneka tokoh fiktif dan dramatisasi. Serta yang dipentingkan oleh puisi esai ialah renungan atas kandungan moral melalui sebuah kisah. Artikel ini mencoba meninjau dari aspek sosiologi sastra, yaitu hubungan antara pengarang, karya, dan masyarakat. Antologi ini berisi lima puisi esai, kisah yang ditampilkan beragam mulai dari dilema seorang pelajar SMA karena terenggut keperawanannya hingga berdampak kepada masa depannya; kisah seorang gadis desa yang merasa tersakiti hatinya atas kondisi ekonomi dan kisah cinta yang memprihatinkan; kisah seorang perempuan yang diberasarkan melalui kekerasan dalam keluarga; kisah keluarga tanpa sosok ayah, istri dan anaknya harus menelan kerasnya kehidupan; dan situasi sosial yang dialami pengarang yang berhubungan dengan manusia, alam, dan Tuhan.
\end{abstract}

Kata Kunci: konflik sosial, puisi esai, sosiologi sastra

\section{A. Pendahuluan}

Puisi esai dianggap sebagai genre sastra baru dalam khazanah karya sastra. Kemunculan puisi esai dianggap sebagai genre baru dalam kesusastraan yaitu dengan munculnya Denny JA sebagai konsultan politik yang memunculkan gagasan sosialisnya melalui antologi puisi esai berjudul Atas Nama Cinta pada tahun 2012.

\footnotetext{
${ }^{1}$ Penulis adalah dosen tetap pada program studi pendidikan bahasa Indonesia di Universitas Majalengka. Lahir di Tasikmalaya, 15 September 1989. S1 Pendidikan Bahasa dan Sastra Indonesia, UNIGAL Ciamis; S2 Pendidikan Bahasa Indonesia, UPI Bandung; dan saat ini sedang menempuh studi Doktoral program Pendidikan Bahasa di UNJ (Universitas Negeri Jakarta). Menulis buku Sastra untuk Pelajar (MKS Publishing, 2014), Buku Teks Pelajaran Bahasa Indonesia Kurikulum 2013 Edisi Revisi (Kemendikbud, 2016), dan Implementasi Gagasan dalam Karya Tulis IImiah (Insan Cerdas Bermartabat, 2017).
} 
Dalam artikel ini akan membahas mengenai kenyataan sosial yang dialami oleh sejumlah tokoh lengkap dengan tragedi atau peristiwa yang melatarbelakanginya dalam suatu lingkungan sosial masyarakat. Konflik terjadi ketika adanya kesenjangan antara harapan dan kenyataan dalam hidup.

Karya sastra menjadi unggul bukan hanya bentuk yang disajikan melainkan dari isi atau arti. Pembaca dapat memahami makna, menghayati alur cerita, bahkan mampu menjadi pembangkit ragam perasaan tentu dari kepiawaian penulis dalam menyajikan isi cerita yang memiliki arti

Terdapat lima judul puisi esai dalam Antologi Puisi Esai: Serat Kembang Raya ini. Semua cerita berdasarkan kenyataan yang terjadi dalam ruang lingkup masyarakat. Fatin Hamama, dkk menyuguhkan konflik sosial yang dialami manusia pada umumnya, seperti dalam puisi esai berjudul Orang-orang Gila Berpuisi oleh Akidah Gaudzillah yaitu dilema seorang pelajar yang berharap menemukan cinta sejati dan masa depannya namun terganjal oleh keperawanan yang telah terenggut; Serat Klara Ati oleh Anis Sholeh Ba'asyin yaitu kisah seorang tokoh yang dikategorikan sebagai perempuan desa yang tersakiti hatinya. Peristiwa sarat konflik terjalin melalui kondisi sosialnya yang hidup di desa, kisah cinta yang berbalut kekejaman, serta perekonimian yang memprihatinkan; Kisah Luka Mutiara oleh Dianing Widya yaitu kisah seorang perempuan yang belum merasakan kebahagiaan dalam keluarga dan pernikahannya, terlahir dalam keluarga yang penuh kekerasan. Jelaga Kembang Raya oleh Fatin Hamama yaitu kisah keluarga tanpa sosok ayah, istri dan anak-anaknya harus merasakan hidup dalam keterbatasan dan penderitaan; dan Hong oleh Sujiwo Tejo yaitu ungkapan pengarang dalam mencermati fenomena sosial yang dialami berbagai tokoh serta berhubungan dengan manusia, alam, dan Tuhan.

Isu-isu masalah sosial yang diangkat dalam karya sastra dengan didukung faktafakta, merupakan penyesuaian diri dengan perkembangan hidup masyarakat.

\section{B. Pembahasan}

\section{Puisi Esai Sebagai Karya Sastra}

Sastra selalu menyajikan sesuatu hal yang unik, bersagam, dan bermakna kepada setiap pembaca. Peristiwa yang dihadirkan mampu membuat siapapun masuk ke dalam jalan cerita yang dibuat oleh penulis. Karya sastra sebagai karya imajinatif dari penulisnya bukan berarti hanya khayalan, rekayasa, atau replika semata tanpa ada pesan atau tragedi berdasarkan kenyataan dari kehidupan baik pribadi maupun orang lain.

Puisi di samping karya sastra lain memiliki peran penting dalam menyuarakan perasaan dan pikiran penyair atas berbagai fenomena yang terjadi melalui bahasa imajinatif, bermakna kias yang tersusun secara sistematis dalam tipografi. Bellefonds, dkk (1993: 789) mengartikan puisi adalah seni untuk membangkitkan kesan, perasaan, atau menggambarkan benda melalui harmoni suara dan irama kata-kata.

Dalam perjalanannya puisi mengalami perubahan dan perkembangan. Pradopo (2005: 3) menyatakan bahwa puisi selalu berubah-ubah sesuai dengan evolusi selera dan perubahan konsep estetikanya. Perubahn dan perkembangan yang terjadi saat ini dalam puisi ialah terintegrasinya esai dalam puisi. Esai dipahami sebagai karangan dalam bentuk prosa yang membahas masalah secara sepintas lalu dari sudut pandang pribadi penulisnya. Eneste (1994: 71) menyatakan bahwa esai adalah karangan nonfiksi mengenai suatu hal tertentu. Di dalamnya kelihatan pandangan atau sikap penulisnya secara pribadi. Pembeda puisi dan esai ialah 
penyajian dan sudut pandang dari penulis. Sajian berupa kata-kata kiasan, majas, dan diksi serta uraian deskripsi dari penulis melalui sudut pandangnya terutama berdasarkan kenyataan sosial. Penanda dalam puisi esai ialah adanya catatan kaki atau footnote.

Adapun karakteristik atau ciri khasi yang menjadi syarat dari puisi esai yang memadukan bentuk puisi dengan bentuk esai ialah sebagai berikut.

a) puisi esai mengeksplor sisi batin individu yang berada dalam sebuah konflik sosial;

b) puisi esai menggunakan bahasa yang mudah dipahami;

c) puisi esai adalah fiksi. Boleh saja memotret tokoh ril yang hidup dalam sejarah. Namun, realitas tersebut diperkaya dengan aneka tokoh fiktif dan dramatisasi yang dipentingkan oleh puisi esai adalah renungan serta kandungan moral yang disampaikan lewat sebuah kisah, bukan semata potret akurat sebuah sejarah.

\section{Konflik Sosial dan Sosiologi Sastra}

Dalam kehidupan masyarakat terdapat beragam fenomena sosial, salah satunya konflik sosial. Konflik secara harfiah dimaknai sebagai perselisihan atau pertentangan, sedangkan sosial dimaknai sebagai berkenaan dengan masyarakat. Suatu pertentangan yang terjadi dalam masyarakat. Konflik dikategorikan sebagai gejala sosial yang hadir dalam kehidupan masyarakat yang bersifat inheren yaitu senantiasa ada dalam setiap ruang dan waktu, di mana saja dan kapan saja.

Nurgiyantoro (2002: 122) menyatakan bahwa konflik adalah sesuatu yang bersifat tidak menyenangkan yang terjadi dan atau dialami oleh tokoh-tokoh ceria, yang jika tokoh-tokoh itu mempunyai kebebasan untuk memilih, ia (mereka) tidak akan memilih peristiwa itu menimpa dirinya. Sementara, Sayuti (2002: 142) menyatakan bahwa konflik sosial adalah konflik antara orang-orang atau seseorang dengan masyarakat. Wujud konflik tersebut biasanya konflik tokoh dalam kaitannya dengan masalah-masalah sosial. Oleh karena itu, jika manusia tidak segera mencari jalan keluarnya, dapat menimbulkan konflik. Konflik timbul dari sikap individu terhadap lingkungan sosial mengenai berbagai masalah, misalnya pertentangan ideologi, pemerkosaan hak, dan lain sebagainya. Dengan demikian, konflik baik dalam cerita imajinatif atau pun dunia nyata merupakan sesuatu yang tidak diinginkan hadir dalam kehidupan, sebab memiliki efek negatif terhadap sesama individu atau kelompok, mampu mengubah pola perilaku masyarakat.

Setiadi dan Usman (2011: 361) mengemukakan faktor-faktor penyebab terjadinya konflik terbagi menjadi dua yaitu kemajemukan horizontal dan kemajemukan vertikal. (1) Kemajemukan horizontal adalah struktur masyarakat yang majemuk secara kultural seperti, suku bangsa, agama, ras, dan majemuk sosial dalam arti perbedaan pekerjaan dan profesi seperti petani, buruh, pedagang, pengusaha, pegawai negeri, militer, wartawan, alim ulama, sopir, dan cendekiawan. Kemajemukan horizontal-kultural menimbulkan konflik yang masing-masing unsur kultural tersebut mempunyai karakteristik sendiri dan masing-masing penghayat budaya ingin mempertahankan karakteristik budayanya tersebut. Dalam masyarakat yang strukturnya seperti ini, jika belum ada konsensus nilai yang menjadi pegangan bersama, konflik yang terjadi dapat menimbulkan perang saudara; (2) kemajemukan vertikal, yang artinya struktur masyarakat yang terpolarisasi berdasarkan kekayaan, pendidikan, dan kekuasaan. Kemajemukan vertikal dapat menimbulkan konflik sosial karena ada sekelompok kecil masyarakat yang memiliki kekayaan, pendidikan yang mapan, kekuasaan dan kewenangan yang besar, sementara sebagian besar tidak atau kurang memiliki kekayaan, pendidikan rendahm dan tidak memiliki kekuasaan 
dan kewenangan. Pembagian masyarakat ini merupakan benih subur bagi timbulnya konflik sosial.

Sementara, Narwoko (2005: 68) menjabarkan banyak faktor yang menyebabkan terjadinya konflik-konflik, di antaranya sebagai berikut.

1. Perbedaan pendirian dan keyakinan. Di dalam realitas sosial, tidak ada satupun individu yang memiliki karakter yang sama, sehingga perbedaan pendapat, tujuan, keinginan tersebutlah yang mempengaruhi timbulnya konflik sosial.

2. Perbedaan kebudayaan. Pola-pola kebudayaan yang berbeda akan menimbulkan pola-pola kepribadian dan pola-pola perilaku yang berbeda pula di kalangan khalayak kelompok luas.

3. Perbedaan kepentingan. Mengejar tujuan kepentingan masing-masing yang berbeda-beda, kelompok-kelompok akan bersaing dan berkonflik untuk memperebutkan kesempatan dan sarana.

Berdasarkan pernyataan di atas, timbulnya konflik mampu mengubah sistem nilai-nilai yang berlaku di dalam masyarakat. Perubahan tersebut akan menyebabkan perbedaan-perbedaan pendirian dalam masyarakat. Dengan demikian, konflik bersifat merusak dan mendorong timbulnya konflik lebih lanjut, sehingga menyebabkan perubahan yang tidak dapat dihindari, dan perubahan akan selalui mengarah pada peningkatan mutu manusia, sehingga akan adanya konsekuensi merugikan maupun menguntungkan yang dapat muncul dari terjadinya konflik. Dalam fiksi dan nonfiksi konflik pada hakikatnya merupakan peristiwa, yang dapat menyebabkan satu terjadinya satu dengan yang lain.

Semi (1988: 45) menyatakan konflik dalam fiksi terdiri atas konflik internal yaitu pertentangan dua keinginan di dalam diri seorang tokoh dan konflik eksternal, yaitu konflik antara satu tokoh dengan tokoh yang lain antara tokoh dengan lingkungannya.

Oleh sebab itu, konflik sosial yang terjadi dalam suatu masyarakat yang terjalin antartokoh disebabkan adanya perbedaan sudut pandang yang merupakan bagian dari gambaran kehidupan masyarakat dengan lingkungannya. Gambaran kehidupan tersebut tercermin dalam ragam karya sastra salah satunya puisi esai ini. Dalam melibatkan kehidupan sosial masyarakat perlu adanya pendekatan dalam sastra yaitu sosiologi sastra. Damono (1984: 7) mengungkapkan sosiologi sastra merupakan disiplin ilmu yang mengkaji masyarakat dan sastra, seperti halnya sosiologi, sastra berurusan dengan manusia dalam masyarakat: usaha manusia untuk menyesuaikan diri dan usahanya untuk mengubah masyarakat itu.

Sastra sudah menjadi bagian dalam masyarakat, pola-pola kehidupan suatu masyarakat dapat diungkapkan dalam karya sastra baik permasalahan diskriminasi atau toleransi oleh pengarangnya. Lebih lanjut, Damono (1987: 3-4) mengungkapkan adanya hubungan timbal-balik antara sastrawan, sastra, dan masyarakat. Membagi telaah sosiologi sastra ke dalam tiga bagian, yaitu (1) konteks sosial pengarang, menyangkut posisi sosial masyarakat dan kaitannya dengan masyarakat pembaca, termasuk di dalamnya faktor-faktor sosial yang bisa mempengaruhi pengarang sebagai perseorangan di samping mempengaruhi isi karya sastranya; (2) sastra sebagai cerminan masyarakat, yang ditelaah adalah sejauh mana sastra dianggap sebagai pencerminan keadaan masyarakat; dan (3) fungsi sosial sasta, dalam hal ini sampai seberapa jauh nilai sastra berkaitan dengan nilai sosial, dan sampai berapa jauh nilai sastra dipengaruhi oleh nilai sosial, dan sampai seberapa jauh pula sastra dapat berfungsi sebagai pembaharu, 
pemberontak, penghibur, dan sekaligus sebagai pendidikan bagi masyarakat pembaca.

Sastra menjadi cerminan dalam masyarakat sebab tokoh, alur, latar, atau pesan yang disajikan tidak terlepas dari kenyataan sosial yang ada dan menjadi bagian dari masyarakat. Dengan demikian, diskriminasi sosial sebagai bagian dari sosiologi sastra merupakan bukti bahwa masyarakat, sastra, dan problematikanya menjadi gambaran baik dalam lingkungan dengan manusia lain, atupun hubugan dengan dirinya sendiri.

\section{Puisi Esai Serat Kembang Raya}

Berikut adalah sejumlah puisi esai Serat Kembang Raya beserta analisis konflik sosial.

\section{a) Orang-orang Gila Berpuisi - Akidah Gaudzillah}

Puisi esai ini berkisah mengenai dilema seorang pelajar kelas 3 SMA bernama Maudy. Keperawanannya terenggung secara tidak wajar. Cita-cita dan masa depannya terancam sirna.
Maudy, remaja lugu itu tak berdaya
Dicekoki lagi dan lagi sebotol vodka
Oleh pacarnya yang jauh lebih tua
Di motel yang ia tak kenal area
(hlm. 11)

Maudy menangis bingung

Saat mabuk uangnya diambil pacar

la lihat di kantung

Kosong seperti perutnya lapar

Hati dan perut Maudy bukan main perih

Setelah vodka membuatnya muntah-muntah

la masih terus dikerjai sang kekasih

Uang, Cinta, hingga keperawanan musnah

(hlm. 12)

Maudy merupakan gadis yang berstatus sebagai pelajar SMA. la berpacaran dengan laki-laki yang lebih tua darinya. Tanpa disangka Maudy menjadi korban diskriminasi dari laki-laki yang sudah lama dikenalnya. Perlakuan tersebut berakibat fatal bagi masa depannya dalam menyelesaikan sekolahnya dan mencari cinta sejati dari laki-laki yang akan jadi suaminya kelak.

Kepala Sekolah keluarkan surat pemberhentian sekolah

Ayah Maudy membalas sumpah serapah

Sistem pendidikan apa yang main vonis gegabah

Psikologis remaja akan semakin bermasalah

Ayah menggugat mencari keadilan

Puterinya tertekan malah diputus pendidikan

Lalu ke mana meneruskan masa depan

Kalau dibuang tanpa harapan?

Maudy sudah di bangku kelas 3 SMA, 
harusnya segera ujian

Kok malah dikeluarkan?

Hanya karena kesalahpahaman

Bagi keluarga adalah cobaan

Bagi Maudy mengguncang kejiwaan

(hlm. 16-17)

Konflik yang diamali oleh Maudy dan keluarganya ialah bagaimana menentukan jalan masa depannya yang minimal lulus SMA terlebih dahulu. Namun, apa daya karena masalah yang dialaminya sekolah memutuskan untuk memberhentikan Maudy dari sekolah. Akibat pergaulan bebas yang dialami oleh Maudy merupakan contoh dari sekian banyak orang yang mengalami hal serupa. Kasus tersebut tentu akan mengganggu masalah psikologis baik dari korban ataupun keluarga.

Salah satu keunggulan puisi esai ialah adanya istilah kata yang kadang kurang dipahami oleh pembaca. Untuk memahaminya, penulis menyertakan deskirpsi misalnya kata vodka dijelaskan bahwa vodka adalah sejenis minuman beralkohol tinggi, bening, dan tidak berwarna, yang biasanya disuling dari gandum yang difermentasi. Selain itu psikologi remaja dijelaskan bahwa individu di usia remaja berada dalam periode storm and stress (badai dan tekanan) dan sedang mengalami hightened emotionality (kepekaan emosi yang meningkat), sehingga emosi individu di masa remaja cenderung unstabil (labil) dan sangat sensitif.

\section{b) Serat Klara Ati - Anis Sholeh Ba'asyin}

Puisi esai ini berkisah mengenai seorang perempuan bernama Dewi alias Warsi yang merasa dirinya selalu tersakiti, hidup di desa dengan keterbatasan ekonomi, serta kisah cinta yang sarat kekejaman. Desa tempat ia tinggal jauh dari masa depan yang ia impikan.

ljinkan kuperkenalkan diri,

namaku: Dewi

orang menyebutku: Klara Ati

selalu aku dipanggil: Dewi Klara Ati

Aku lahir di Dukuhteri

desa kecil yang banyak sakit hati.

O ya, di desa jangan panggil aku Dewi

orang akan melongo tak mengerti

mereka cuman kenal aku sebagai Warsi

gadis lugu yang tiap sore rajin mengaji.

(hlm. 38)

Apa yang harus kukatakan

Desaku bukan desa impian

Pendapatan rata-rata tidak menggembirakan

Sawah bukan lagi sumber kehidupan,

Tak menjamin masa depan

Sebagian digerogoti warisan,

Sebagian dijual demi kebutuhan

dan menjelmalah barisan buruh, 
yang makin hari makin mengisah peluh

Kerja hanya cukup untuk makan, kadang malah kurang

Banyak yang akhirnya terbang ke kota

atau ke manca negara, tanpa bekal

Kecuali perut keroncongan.

(hlm. 39)

Dewi alias Warsi menamakan dirinya Klara Ati, dalam bahasa Jawa memiliki arti yang tersakiti hatinya. Rasa sakit hati Warsi tidak lain karena masalah ekonomi hingga memunculkan konflik dalam diri terhadap lingkungan sosial. Desa tempat ia tinggal bernama Dukuhteri. Desanya tidak menjanjikan harapan besarnya untuk bisa sukses terutama dalam mengubah keadaan ekonominya. Puisi esai ini diilhami berdasarkan kisah nyata di suatu desa pada tahun 1980an, sebagian perempuan yang berstatus istri, bersedia melacurkan diri demi menaikkan taraf hidup mereka. Hal tersebut bisa atas inisiatif sang istri atau permintaan suami atau hasil kompromi bersama. Peristiwa tersebut berdasakan kondisi Indonesia pada masanya.

\section{c) Kisah Luka Mutiara - Dianing Widya}

Puisi esai ini berkisah mengenai seorang perempuan bernama Mutiara yang terlahir dalam keluarga yang sarat akan pertengkaran dan kekerasan dalam rumah tangga. Sehingga ia sepanjang hidupnya belum pernah merasakan kebahagiaan, sekalipun bersama suami dan anaknya.

Namaku Mutiara

Aku biasa dipanggil Tiara

Namaku indah penuh cahaya

Tetapi tidak dengan nasibku

Bila malam hadir

Aku sering berpikir

Apa arti pernikahan

Bukankah untuk mencipta bahagia

Bukan merajut pertengkaran

Kenyataan mereka menyulam bara

Masa kanak dan remajaku

Bagai dalam derap kuda perang

Hak bersenang-senang hanya bayang

Ayah seperti lupa kehadiranku

la lebih sering memamerkan taringnya

Semestinya ayah menyayangi ibu

Hingga tak ada hari berwajah kelabu

Agar aku tak benci pada ayah

Agar aku tak hidup dalam cemas

(hlm. 73-74)

Konflik sosial yang tampak dalam puisi esai ini ialah tokoh Mutiara yang mengalami pasang surut perasaan dan pikirannya dari serangkaian pengalaman 
pahit yang dialaminya. Pernikahan yang ia rajut belum berakhir bahagia, yang ia dapat hanya kepedihan. Hal tersebut berlaku juga ketika ia dalam asuhan ibu dan ayahnya. Kondisi keluarga yang kurang mendukung perkembangannya yang seharusnya dihadapkan pada pengalaman positif dan bahagia, layaknya kanak-kanak dan remaja, malah berbanding terbalik. Baginya, ayah bukanlah sosok yang membimbing melainkan sosok kejam dan penebar duka terutama kepada ibunya. Puisi esai ini jika kita hubungkan dengan makna pernikahan dalam Q.S. Ar-Ruum: 21 ialah meraih kebahagiaan dan ketenangan hidup yang sakinah mawaddah wa rahmah. Sedangkan, mengenai kekerasan atau pertengkaran yang terjadi dalam keluarga yang disaksikan oleh anak-anak akan berdampak buruk. Anak bisa membenci ayah karena menyalahkan sang ibu. Anak jadi tidak mau menerima pemberian apapun dari ayah, karena terlanjur benci pada anak.

d) Jelaga Kembang Raya - Fatin Hamama

Puisi esai ini berkisah mengenai kisah keluarga tanpa sosok ayah sebagai kepala keluarga. Istri dan anaknya terpaksa harus mengalami penderitaan yang hidup dalam keterbatasan.

Semanjak ayah pergi meninggalkan ibu dan aku

Beserta tiga orang kakak laki-laki-ku,

maka kami bukan orang 'elok' lagi

Hatiku perang

Untuk apa dia memangil-manggil nama kami

di ujung usianya yang tua dan renta

Kemana dia ketika kami butuh

dan butuh Ayah

Kemana dia ketika kami lapar

Berulang kali kakakku Julius meneleponku

menyuruh dan memaksa bertemu ayah

Hatiku enggan, dan ragu

luka batinku lama berdarah dan sakit

Sampai siang tadi

dengan suara terbata dia kembali memaksaku

"Apapun marahmu Ana, tapi Ayah sedang sekarat" katanya

"datanglah kemari kami menunggumu".

(hlm. 101)

Ayah pun pergi meninggalkan lbu

dengan segala yang terkuras dan tandas di meja judi

Kembali ke kampungnya, dan mencari wanita lain.

Kami sering kelaparan dan ibu membagi sepiring nasi

pada mangkok kami berlima

Kadang tanpa lauk dan hanya taburan garam

Kadang juga mangkok ibu kulihat kosong

Ibu membaginya kepada kami berempat 
dan ibu menahan lapar

Aku lihat keringat ibu bergulir ketika menumbuk padi Tangan halus itu kini kasar dan kapalan

(hlm. 102-103)

Ana salah satu anak yang ditinggalkan oleh ayahnya, perasaan dan pikirannya semakin menjadi benci dan murka sekalipun ayahnya sedang sekarat. Kebencian Ana bertambah ketika ia ingat tragedi yang tentang kebiasaan ayahnya yang sering menghabiskan uang hanya untuk berjudi dan mencari wanita lain. Ana turut merasakan penderitaan ibu yang harus kerja keras untuk bisa memberi makan anak-anaknya. Dalam puisi esai ini, selain dari tokoh Ana sebagai anak, konflik sosial tampak pada seorang ibu yang harus menjadi single parent mengurus dan membesarkan anak-anaknya dan menjadi terlantar, sebagai akibat dari ditinggalkan oleh seorang ayah.

\section{e) Hong - Sujiwo Tejo}

Puisi esai ini pengarang mengisahkan dirinya di sebuah kafe dalam mencermati berbagai fenomena sosial yang terjadi dalam keseharian masyarakat. Ungkapan pengarang dalam mencermati fenomena tersebut berhubungan dengan manusia, alam, dan Tuhan.

Pagi itu tak sesiapa bersamaku.

Tak apa pula yang bersamaku. Belum ada masjid ketika itu.

Burung gereja belum ada terbang.

Mungkin burung-burung itu malah belum ada alamnya.

Kuil-vihara-pura pun belum berupa.

Pagi itu belum ada kata.

Di kafe ini, di bekas tanah makam terbangun kafe, Serdadu meniup saksofon. Tangan kakinya hilang entah perang yang kapan,

Tapi saksofon tenor dilagukannya nyaris sempurna.

Tadi biduan Jayagiri, namanya Melati, melantunkan

Bubuy Bulan asal Pasundan.

Di kafe Kamboja itu, di antara kepul asap rokok, di antara wangi dan suam minuman keras aku terawang wajah-wajah berbagai penjuru. Mereka tak kenal syair Bubuy Bulan.

Hanya satu dua yang parasnya terpaut pengertian. mungkin lantaran mereka dari Priangan Paris Merindu.

(hlm. 136)

Masih ganjil rasanya aku pun memelukmu sembari berlesung kata, tak Cuma lenguh dan desah kuberi pada tubuhmu yang terpelanting abad ke abad.

Ah, bila kata-kata bisa menggenapi bahasa usap, bahasa tatap, bahasa dekap, mengapa tak kulengkapi pula bahasa isyarat Tuhan dengan bahasa kata-kata? 
Sejak itu bagi kami Tuhan bertutur melalui burung kepodang, dan kata-kata. Tuhan bertutur melalui gempa bumi, dan kata-kata.

Tuhan bertutur melalui panas, dingin, dan gigil, dan kata-kata.

Tuhan beralam kata disaksikan kutu-kutu kitab dan atap gedung

Perpustakaan sisi resotoran ala Korea. Kata-kata itu sakral.

Tutur kata alangkah luhur.

(HIm. 144)

Puisi esai ini, sarat akan fenomena sosial berupa situasi atau kondisi masyarakat dibandingkan dengan sebuah konflik. Pada halaman 136, pengarang menyampaikan suatu situasi yang sering banyak orang alami, yaitu singgah di sebuah kafe. Pengarang mencermati segala aspek di sekitar berikut penelusuran secara historis dari asal-usul kafe tersebut. Dalam puisi esai ini, pengarang menyertakan istilah lagu Bubuy Bulan sebagai nyanyian rakyat Jawa Barat. Bahwa hanya sedikit yang akrab dengan lagu lokal yang diperdengarkan dalam sebuah kafe, bahkan tempat-tempat lain. Sementara, istilah Melati dari Jayagiri adalah lagu Bimbo yang dinyanyikan oleh lin Parlina, tentang seseorang yang menjadi sinar hati, yang entah segala kenangannya akan tinggal kenangan atau tidak. Sedangkan, pada halaman 144 , yang menjadi fokus utama ialah "bahasa Tuhan". Segala yang ada di alam semesta ini ciptaanNya, Tuhan berbahasa kepada makhluk bukan seperti manusia berbahasa pada umumnya. Melainkan dengan kekuasaannya, melalui tanda-tanda alam semesta, iklim cuaca, bahkan makhluk ciptaannya, dalam hal ini seorang pemuka agama melalui kitab keyakinannya yang diajarkan kepada masyarakat luas.

\section{Simpulan}

Sastra sebagai salah satu karya yang mampu menghadirkan berbagai fenomena sosial selalu menyuguhkan nuansa berbeda dibandingkan dengan karya tulis lainnya. Berbagai fenomena yang terjadi tidak lepas dari intelektualitas para pengarang dalam menyajikannya. Pola imajinasi, realitas, dan pengalaman merupakan hal inwal dalam terciptanya karya sastra yang berkualitas yang dapat dinikmati oleh khalayak pembaca. Oleh sebab itu, sastra merupakan personifikasi kreativitas manusia. Perkembangan sastra selalu mencerminkan kecenderungan manusia dan masyarakatnya. Bahkan, sastralah yang paling representatif dalam mengekspresikan nilai-nilai yang dianut masyarakat.

Dikatakannya sebagai genre baru dalam kesusastraan Indonesia, puisi esai mampu menghadirkan gagasan realitas sosial melalui bentuk larik dan sudut pandang pribadi penulis dengan gaya khas esai. Selain itu, menjadi penambah khazanah kesusastraan terlepas kontroversi yang terjadi karena kemunculannya. Puisi esai mampu menyatukan ideologi pengarang yang berfokus pada problematika sosial yang terjadi dalam ruang lingkup masyarakat. Puisi esai menjadi peluang untuk memanfaatkan kemampuan, pengalaman, dan pengetahuan tentang bidang yang ditekuni selama untuk ditulis menjadi puisi.

\section{Daftar Pustaka}

Aminuddin. (1987). Pengantar apresiasi sastra. Yogyakarta: Sinar Baru. 
Damono, Sapardi Djoko. (1978). Sosiologi sastra sebuah pengantar ringkas. Jakarta: Pusat Pembinaan dan Pengambanan Bahasa Departemen Pendidikan dan Kebudayaan.

Endraswara, Suwardi. (2003). Metodologi penelitian sastra. Yogyakarta: Pustaka Widyatama.

Ferarra, Cosmo F. (1991). Introducing literary. New York: Glencoe/McGraw-Hill Educational

Hamama, Fatin, dkk. (2014). Antologi puisi esai: serat kembang raya. Depok: PT. Jurnal Sajak Indonesia.

Lawang, Robert. (1994). Buku materi pokok pengantar sosiologi. Jakarta: Universitas Terbuka.

Narwoko, J. Dwi. (2005). Sosiologi teks pengantar dan terapan. Jakarta: Kencana Prenada Media Group.

Noor, Acep Zam-zam (ed). (2013). Puisi esai: kemungkinan baru dalam puisi Indonesia. Depok: PT. Jurnal Sajak Indonesia.

Nurgiyantoro, Burhan. (2005). Teori pengkajian fiksi. Yogyakarta: Gajah Mada University.

Ratna, Nyoman Kutha. (2007). Teori, metode, dan teknik penelitian sastra. Yogyakarta: Pustaka Pelajar.

Sayuti, Suminto A. (2000). Berkenalan dengan prosa. Yogyakarta: Gama Media.

Semi, M Atar. (1988). Anatomi sastra. Padang: Sidharma.

Setiadi, Elly M \& Usman Kolip. (2011). Pengantar sosiologi pemahaman fakta dan gejala permasalahan sosial: teori, aplikasi, dan pemecahannya. Jakarta: Kencana Prenada Media Group. 